\title{
A comparative study of pneumomediastinums based on clinical experience
}

\author{
(1) Ersin Sapmaz, M.D., ${ }^{\oplus}$ Hakan Işık, M.D.,' $\odot$ Deniz Doğan, M.D., ${ }^{2}$ \\ (1) Kuthan Kavaklı, M.D., ${ }^{\circledR}$ ○ Hasan Çaylak, M.D. ${ }^{1}$ \\ ${ }^{1}$ Department of Thoracic Surgery, Gülhane Training and Research Hospital, Ankara-Turkey \\ ${ }^{2}$ Department of Pulmonology, Gülhane Training and Research Hospital, Ankara-Turkey
}

\begin{abstract}
BACKGROUND: Pneumomediastinum (PM) is the term which defines the presence of air in the mediastinum. PM has also been described as mediastinal emphysema. PM is divided into two subgroups called as Spontaneous PM (SPM) and Secondary PM (ScPM).

METHODS: A retrospective comparative study of the PM diagnosed between February 2010 and July 2018 is presented. Forty patients were compared. Clinical data on patient history, physical characteristics, symptoms, findings of examinations, length of the hospital stay, treatments, clinical time course, recurrence and complications were investigated carefully. Patients with SPM, Traumatic PM (TPM) and latrogenic PM (IPM) were compared.
\end{abstract}

RESULTS: SPM was identified in 14 patients (35\%). In ScPM group, TPM was identified in 16 patients (40\%), and IPM was identified in 10 patients (25\%). On the SPM group, the most frequently reported symptoms were chest pain, dyspnea, subcutaneous emphysema and cough. CT was performed to all patients to confirm the diagnosis and to assess the possible findings. All patients prescribed prophylactic antibiotics to prevent mediastinitis.

CONCLUSION: The present study aimed to evaluate the clinical differences and managements of PMs in trauma and non-trauma patients. The clinical spectrum of pneumomediastinum may vary from benign mediastinal emphysema to a fatal mediastinitis due to perforation of mediastinal structures. In most series, only the SPM was evaluated in many aspects, but there are fewer studies comparing the evaluation and management of traumatic and non-traumatic PMs. The patients with TPM who have limited trauma to the thorax and who do not have mediastinal organ injury in their imaging studies can be followed up and treated like SPM patients who do not have mediastinal organ injury, and both have good clinical course.

Keywords: Mediastinal emphysema; mediastinitis; spontaneous pneumomediastinum; traumatic pneumomediastinum.

\section{INTRODUCTION}

Pneumomediastinum (PM) is a term that defines the presence of air in the mediastinum. PM has also been described as mediastinal emphysema. ${ }^{[1]}$ The entity was first described by Laenek in 1827. ${ }^{[1]} \mathrm{PM}$ is divided into two subgroups called Spontaneous PM (SPM) and Secondary PM (ScPM). The ScPM group is made up of the combination of Traumatic PM (TPM) and latrogenic PM (IPM) groups (Fig. I).
SPM is an uncommon, self-limiting condition that often presents with sudden onset of symptoms, including chest pain, neck pain, dyspnea or signs of subcutaneous emphysema. SPM is classified as free air in the mediastinum without any traumatic or iatrogenic cause. ${ }^{[2]}$ However, in many reports, the term SPM has been allowed even when a possible triggering factor is identified. ${ }^{[1-3]}$ Triggering factors, such as asthma,

Cite this article as: Sapmaz E, Işık H, Doğan D, Kavaklı K, Çaylak H. A comparative study of pneumomediastinums based on clinical experience. Ulus Travma Acil Cerrahi Derg 2019;25:497-502.

Address for correspondence: Ersin Sapmaz, M.D.

Gülhane Eğitim ve Araştırma Hastanesi, Göğüs Cerrrahisi Anabilim Dalı Başkanlığı, Ana Bina, 6. Kat, Etlik, Ankara, Turkey

Tel: +90 312 - 30451 7I E-mail: esapmaz@hotmail.com

Ulus Travma Acil Cerrahi Derg 2019;25(5):497-502 DOI: 10.14744/tjtes.2019.0316I Submitted: 29.1I.2018 Accepted: 20.05.2019 Online: 22.08.2019

Copyright 2019 Turkish Association of Trauma and Emergency Surgery 


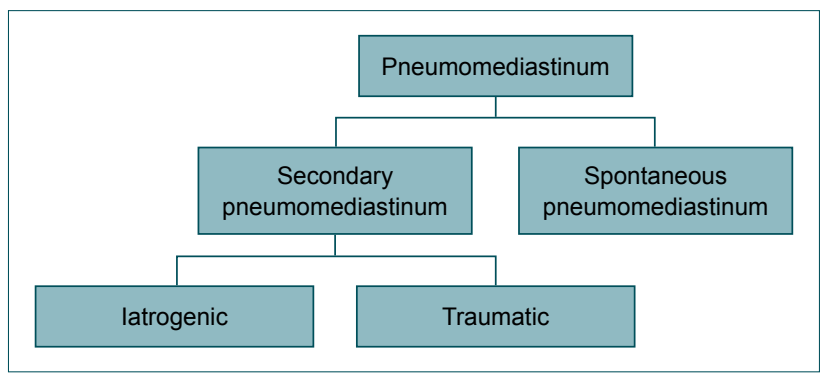

Figure 1. Classification of PM.

vomiting, Valsalva maneuver, drugs, exercise, or severe cough, may be associated with SPM. ${ }^{[2]}$ SPM is generally benign and self-limiting condition, presenting in young adults exposed to a sudden pressure change within the thoracic cavity. ${ }^{[4,5]}$ In $\mathrm{ScPM}$, there is a specific responsible pathologic event such as trauma, surgery and damage of the aerodigestive tract.

This study aims to investigate the presenting features, similarities or differences for clinical management of SPM, IPM and TPM, and identify the required follow up time of hospitalized adult patients who were treated between January 2010 and July 2018.

\section{MATERIALS AND METHODS}

A retrospective comparative study of the PM diagnosed between January 2010 and July 2018 is presented. The confirmation of PM (free air in the mediastinum) was made via chest $\mathrm{X}$-ray and thorax computed tomography (CT). Clinical data on patient history, physical characteristics, symptoms, and findings of examinations, length of the hospital stay, treatments, clinical time course, recurrence and complications were investigated carefully. This study was approved by the institutional board review at our institution.

Patients with SPM, TPM and IPM were compared. Only adult patients ( $>18$ years) included in this study. Patients who had no history of trauma or medical intervention, subcutaneous emphysema or the presence of clinical picture consistent with PM were counted as SPM. Only the blunt thoracic trauma with PM who did not require thoracotomy and the integrity of the thorax was protected patients were included in this study and classified as TPM. PM after major thoracic surgeries, such as sternotomy, thoracotomy, or tracheal surgery, was excluded from IPM group in this study.

\section{RESULTS}

According to the inclusion and exclusion criteria previously defined, 40 patients included in this study. SPM was identified in 14 patients (35\%). All of the patients were male.

On the SPM group, the clinical presentations were identified according to the patient's complaints and physical examinations recorded to the medical records. The most frequently reported symptoms were chest pain in $43 \%$ (6 of I4) and dyspnea in $43 \%$ ( 6 of 14 ), followed by subcutaneous emphysema in $29 \%$ ( 4 of 14) and cough in $21 \%$ ( 3 of 14). Pneumothorax was present in $21 \%$ of patients ( 3 of 14) upon admission. The pneumothorax in each patient needed to be treated by chest tube and evident both on the chest x-ray and chest CT scan (Table I). Average recovery time for these patients was 5.2 days ( 3 to 9 days). One patient $(7 \%)$ needed tube insertion to the mediastinum. Recovery time for this patient was five days. One or more preexisting lung disorders were identified in four patients (29\%). Two patients (14\%) had evidence of cryptogenic organizing pneumonia, and two patients (14\%) had evidence of lung cancer. Esophagoscopy was performed to three $(21 \%)$ patients and two of them had both esophagoscopy and fiberoptic bronchoscopy $(7 \%)$. None of the patients had mediastinal organ injury. One of the patients (7\%) who had both esophagoscopy and fiberoptic bronchoscopy scanning had six times of recurrence. There were no in-hospital deaths.

Patients with PM who did not fulfill the criteria previously defined for SPM were considered to have ScPM. This group consisted of 10 (25\%) IPM patients and 16 (40\%) TPM patients.

In ScPM group, pneumothorax was present in $46 \%$ of patients ( 12 of 26) and all needed to be treated by a chest tube. Average recovery time for these patients was 6.6 days (3 to 15 days). Mediastinal chest tube insertion required in $12 \%$ (3 of 26) of the patients. Average recovery time for these patients was 5.3 days ( 5 to 10 days). Nineteen percent of the patients (5 of 26) were male. Average recovery time for ScPM group was 6.2 days (range 2 to 15). The mortality rate was I2\% (3 of 26 ).

IPM was identified in 10 patients (25\%). IPM group included patients in whom PM developed as a result of tracheostomy procedure in $30 \%$ (3 of 10), after endoscopy in 30\% (3 of 10 ),

Table I. SPM, clinical findings on presentation

\begin{tabular}{lll}
\hline Clinical findings & $\mathbf{n}$ & $\%$ \\
\hline Chest pain & 6 & 43 \\
Dyspnea & 6 & 43 \\
Subcutaneous emphysema & 4 & 29 \\
Cough & 3 & 21 \\
Neck swelling & 3 & 21 \\
Pneumothorax & 3 & 21 \\
Dysphagia & 2 & 14 \\
Pneumorrhachis & 1 & 7 \\
Tingling in hands & 1 & 7 \\
Incidentally & 1 & 7 \\
\hline
\end{tabular}

SPM: Spontaneous pneumomediastinum. 
after ERCP procedure in 20\% (2 of 10), after a dental procedure in $20 \%$ (2 of I0). Pneumothorax was present in $30 \%$ of the patients ( 3 of 10 ) and all needed to be treated by a chest tube. Average recovery time for these patients was eight days (4 to 15 days). Mediastinal chest tube insertion was required in $20 \%$ ( 2 of 10$)$ of the patients. Average recovery time for these patients was 7.5 days (5 to 10 days). Sixty percent of the patients (6 of 10$)$ were male. Mortality rate was $20 \%$ (2 of 10).

TPM was identified in 16 patients (40\%). The patients whose integrity of the thorax was protected were included in this group. Pneumothorax was present in $56 \%$ of patients ( 9 of 16) and all of them required chest tube insertion. Average recovery time for these patients was six days (three to 10 days). One patient died due to organ failure (kidney failure and sepsis), which was not related to TPM. One patient (6\%) required substernal tube insertion. Recovery time of this patient was six days. Two patients had Fiberoptic Bronchoscopy screening and no mediastinal organ injury was found. Ninetyfour percent of the patients (15 of 16) were male.

The treatment/follow-up periods for SPM, IPM and TPM cases were $6.0 \pm 1.8,6.7 \pm 3.6$ and $5.8 \pm 2.3$ days, respectively and were not statistically significant $(p=0.687)$. The patients' discharge is planned according to patients' clinical and radiological improvement and observing the decrease of pneumoderma. The age of SPM, IPM and TPM cases were $34 \pm 17$, $49.1 \pm 24$ and 39.9 \pm 15.6 , respectively, and the difference was not statistically significant $(p=0.159)$. This is thought to be due to an insufficient number of patients.

CT was performed to all patients to confirm the diagnosis and to assess the possible findings. A typical chest CT of PM was shown in Figure 2. In the SPM and TPM group, the oral

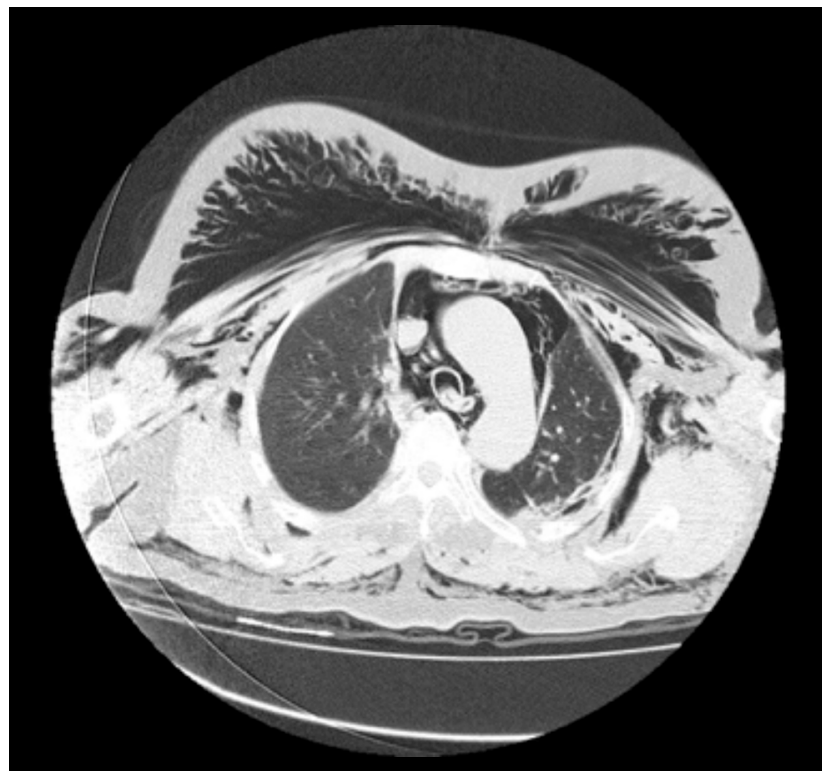

Figure 2. A typical chest CT image of a PM case. intake of patients with suspected mediastinal organ injury was discontinued until the results of the patients were examined. Only the patients underwent mediastinal drainage for worsening subcutaneous emphysema with severe respiratory distress. Prophylactic antibiotics were given to all patients in order to prevent mediastinitis.

\section{DISCUSSION}

The main purpose of this study is to evaluate the clinical differences and managements of PMs in trauma and non-trauma patients. The clinical spectrum of PM may vary from benign mediastinal emphysema to a fatal mediastinitis due to perforation of mediastinal structures (i.e. esophageal perforation). In most series, only the SPM was evaluated in many aspects, ${ }^{[2-4,6,7]}$ but we should note that there are fewer studies that have compared the evaluation and management of traumatic and non-traumatic PMs. ${ }^{[8,9]}$

The pathogenesis of spontaneous pneumomediastinum was first described by Macklin. ${ }^{[10]}$ The pathophysiology is based on a pressure gradient between the alveolus and the lung interstitium. This pressure gradient may lead to alveolar rupture and the consequent flow of air into the interstitium. Once the air is in the lung interstitium, it flows towards the hilum and the mediastinum along a pressure gradient between the lung periphery and the mediastinum. ${ }^{[4, I I]}$

Crepitus heard with the heartbeat on chest auscultation, the pathognomonic sign of spontaneous pneumomediastinum, known as Hamman's ${ }^{[12]}$ sign, which was described by Hamman in 1939. There were no Hamman's sign on the physical examination of our patients.

SPM without any other complications has a benign clinical course. Recurrence is very rare and if an accompanying complication exists, it can cause death. SPM often presents with chest pain, dyspnea and subcutaneous emphysema. These findings were also seen in our patients and consistent with most of the other authors' observations. ${ }^{[2,4,7]}$

SPM has been associated with some triggering factors, including cough, asthma, inhaled drug use, interstitial lung disease, physical exercise, respiratory infection and lung cancer. Kouritas et al. reviewed in their paper that some authors exclude patients from the SPM group if there is any causative factor for PM. ${ }^{\left[{ }^{[}\right]}$However, in our and other studies, ${ }^{[3,4,7]}$ the patients with triggering factors were included in SPM group if there was no surgery, trauma or other iatrogenic factors. Chalumeau et al. ${ }^{[13]}$ noted that exclusion PNMD with a pulmonary disease from SPM had no clinical value. Dionísio et al. ${ }^{[7]}$ found that $88.9 \%$ of patients had a triggering factor. We believe that when a patient with SPM was evaluated with detailed anamnesis, physical examination and laboratory tests for suspicious triggering factor, the patient can be found to have any triggering factor. 
Recurrence is very rare. Caceres et al. ${ }^{[9]}$ reported no recurrence in $79 \%$ of the patients in the follow-up period of one to ten years and found a few case reports for recurrence in the literature. In our study, one of the patients in the SPM group had six times of recurrence. The patient had both esophagoscopy and fiberoptic bronchoscopy scanning and no pathological finding was found. After a detailed investigation, we learned that he was a soldier and was rested for a while after PM. He was abusing this situation by forcing himself to do the Valsalva maneuver.

Three patients had pneumothorax requiring a tube thoracostomy and one patient required substernal tube insertion. Esophagoscopy was performed to three patients and two of them had both esophagoscopy and fiberoptic bronchoscopy but no additional findings like esophageal and tracheobronchial ruptures were detected. The main issue is to determine any suspicious underlying complications, especially esophageal perforation. Most of the authors describe highrisk factors for such patients. Younger age elevated white blood cells as a sign of inflammation and pleural effusion are considered high-risk factors for further diagnostic workup. ${ }^{[2,4]}$ Gupta et al. ${ }^{[14]}$ stated that spontaneous perforation of the esophagus had a much higher mortality rate when comparing other etiologies of esophageal perforation, such as traumatic or iatrogenic factors. Observation can be enough for patients with no severe symptoms or inflammatory signs. ${ }^{[3]}$

The mean hospital stay for the SPM group was 5.2 days. Hospitalization times were reported between 1.8 days and 8.56 days in the most series. ${ }^{[4]}$ The potential complications, such as pneumothorax or tension pneumomediastinum, can occur in the first 24-48 hours of admission, so we suggest that the patients should be hospitalized for at least 24-48 hours. In our study, one patient required tube mediastinotomy 24 hours after admission. Tube mediastinotomy was performed due to the patient's persistent pneumomediastinum and subcutaneous emphysema resulting in respiratory distress. He had no pneumothorax and also required dermal needle puncture. Tube mediastinotomy and dermal needle puncture can be used safely to decrease the pneumoderma and mediastinal pressure to avoid respiratory distress and possible tracheal membrane collapse. None of our patients developed tracheal membrane collapse. Our clinical observations for hospital stay shows concordance with Takada's ${ }^{[3]}$ study. We think that the follow-up of outpatients without hospitalization as applied by Ebina et al. ${ }^{[4]}$ should be limited by some criteria.

Some authors found it unnecessary or avoid using prophylactic antibiotics in SPM patients, ${ }^{[3,4]}$ but we used prophylactic antibiotics in our SPM patients routinely. The use of prophylactic antibiotics may vary depending on the complication of the patients during hospital follow-up.
Many studies have shown that the chest X-ray is not sufficient to diagnose alone. In the literature, the rate at which $\mathrm{X}$-rays cannot be diagnosed varies between $5 \%$ and $33 \%^{[3,6,9]}$ and computed tomography has become the gold standard and considered as a routine diagnostic modality for diagnosing the PM. ${ }^{[1,9]}$ All of our patients had computed tomography imaging on admission to the emergency department. One patient in the SPM group had pneumorrhachis on admission which, is seen very rare in the literature. ${ }^{[15]}$

Traumatic pneumomediastinum was first described by Laennec in 1819 in a 4-year-old boy who was run over by a dung cart. $^{[8,16]}$ The most common mechanism of injury in patients with pneumomediastinum is known to be blunt trauma. [8] Sixteen patients diagnosed PM after blunt trauma in our study. Nine patients (56\%) required tube thoracostomy due to accompanying pneumothorax. One patient required $(6 \%)$ tube mediastinotomy. One patient (6\%) with multiple organ injuries died from another organ injury (kidney failure and sepsis). All patients diagnosed with thorax CT. There was no pleural effusion on radiographic scans. All patients used prophylactic antibiotics.

In the majority of the blunt traumas, Valsalva maneuver was triggered. The severity of the trauma and Valsalva maneuver determine possible complications. However, multi-organ injuries due to blunt traumas that affect other body systems, even though the integrity of the rib cage is not impaired, should be considered separately due to the inability to predict complications that may develop outside of pneumomediastinum. In our series, we found that uncomplicated blunt injuries limited to thorax can be managed like uncomplicated SPM patients. Chest CT scan was not required for patients with isolated blunt thoracic trauma with no symptom or sign. Chest $X$-ray was efficient for the first evaluation for these patients. However, chest CT scan is required for patients who had unexplained severe chest pain, subcutaneous emphysema, dyspnea, and pleural effusion, evident air in the mediastinum at the chest X-ray or white cell increase in blood count. These patients should be followed for at least 24-48 hours in terms of subsequent pneumothorax and additional late complications. Prophylactic antibiotic use should be case sensitive. During hospitalization, we think that there is no need for prophylactic antibiotic use if there is no pleural effusion, no pneumothorax on the chest radiography and no white cell increase in blood count. Banki et al. showed in their study that most studies with blunt traumatic PM had less mediastinal organ injury than penetrating trauma. They also stated that pneumothorax was not associated with mediastinal organ injury, ${ }^{\left[{ }^{[1}\right.}$ which is similar to our study.

Ebina et al. ${ }^{[4]}$ included minor traumas to their study as SPM and they stated that pneumomediastinum with major trauma, such as penetrating injury, was considered secondary pneumomediastinum. However, minor trauma, such as falling on 
one's hips, can trigger a strong Valsalva maneuver, creating high intrathoracic pressure. Therefore, pneumomediastinum with minor trauma has the same mechanism as SPM. In the light of this information, we could not find any significant difference between uncomplicated SPM and TPM patients. Blunt traumas that do not disrupt the thorax integrity of this type can be accepted as SPM group and can be treated like SPM patients.

IPM diagnosed in 10 patients who had a different type of medical intervention. Two patients in the IPM group had a history of the dental procedure. Cases of pneumomediastinum after dental procedures are very rare and still present in the literature as case reports. Two of all IPM patients (20\%) were due to gastrointestinal system procedures. One patient was due to gastric surgery and the other patient was due to ERCP and both of them died. The clinical management of IPM is a completely different entity. The main problem with these patients is diseases/causes. In these patients, PM often remains an innocent complication. In many clinical scenarios, the physician needs to be focused on the main issue. Therefore, patient management in such patients should be patient-based.

\section{Limitations}

Our study has some limitations. First, this is a retrospective observational study, so we could not prove the causes and effects, and our study might have lacked the power to detect complications. Second, we have limited and incomplete follow up data. Third, the criteria for hospitalization depend on attending physician. Fourth, the reason for using prophylactic antibiotics was undescribed.

\section{Conclusion}

The patients with TPM who have limited trauma to the thorax and who do not have mediastinal organ injury in their imaging studies can be followed up and treated like SPM patients who do not have mediastinal organ injury, and both have good clinical course. The most common clinical presentations are chest pain, dyspnea and subcutaneous emphysema. TPM patients with associated injuries and SPM patients who have additional imaging findings, such as pneumothorax or pleural effusion, should be treated according to their clinical findings. In many patients, a chest x-ray is not sufficient to detect PM, and every suspected case should be evaluated with a CT scan. We recommend that patients should be observed for at least 24-48 hours to avoid delayed posttraumatic complications in uncomplicated TPM and SPM patients. Although antibiotic use is optional, it will be appropriate to decide according to the patient's imaging and blood analysis results. Although recurrence is very rare, patients with SPM who have recurrence should be examined in more detail to find underlying diseases. Long-term follow-up is not required for uncomplicated PM patients.

\section{Conflict of interest: None declared.}

\section{REFERENCES}

1. Kouritas VK, Papagiannopoulos K, Lazaridis G, Baka S, Mpoukovinas I, Karavasilis V, et al. Pneumomediastinum. J Thorac Dis 2015;7:S44-9.

2. Potz BA, Chao LH, Ng TT, Okereke IC. Clinical Significance of Spontaneous Pneumomediastinum. Ann Thorac Surg 2017;104:431-5. [CrossRef]

3. Takada K, Matsumoto S, Hiramatsu T, Kojima E, Watanabe H, Sizu M, et al. Management of spontaneous pneumomediastinum based on clinical experience of 25 cases. Respir Med 2008;102:1329-34. [CrossRef]

4. Ebina M, Inoue A, Takaba A, Ariyoshi K. Management of spontaneous pneumomediastinum: Are hospitalization and prophylactic antibiotics needed? Am J Emerg Med 2017;35:1150-3. [CrossRef]

5. Natsuki K, Fumihiro O, Yuichi K, Keisuke I, Yoshie K. Comparison of Spontaneous and Secondary Pneumomediastinum. J Respir Med Lung Dis 2017;2:1022.

6. Iyer VN, Joshi AY, Ryu JH. Spontaneous pneumomediastinum: Analysis of 62 consecutive adult patients. Mayo Clin Proc 2009;84:417-21. [CrossRef]

7. Dionísio P, Martins L, Moreira S, Manique A, Macedo R, Caeiro F, et al. Spontaneous pneumomediastinum: experience in 18 patients during the last 12 years. J Bras Pneumol 2017;43:101-5. [CrossRef]

8. Banki F, Estrera AL, Harrison RG, Miller CC 3rd, Leake SS, Mitchell KG, et al. Pneumomediastinum: Etiology and a guide to diagnosis and treatment. Am J Surg 2013;206:1001-6. [CrossRef]

9. Caceres M, Ali SZ, Braud R, Weiman D, Garrett HE Jr. Spontaneous Pneumomediastinum: A Comparative Study and Review of the Literature. Ann Thorac Surg 2008;86:962-6. [CrossRef]

10. Macklin C. Transport of air along sheaths of pulmonic vessels from alveoli to mediastinum. Arch Intern Med (Chic) 1939;64:913-26. [CrossRef]

11. Macklin MT. Macklin CC. Malignant interstitial emphysema of the lungs and mediastinum as an important occult complication in many respiratory diseases and other conditions: interpretation of the clinical literature in the light of laboratory experiment. Medicine (Baltimore) 1944;23:281-358. [CrossRef]

12. Hamman L. Spontaneous mediastinal emphysema. Bull Johns Hopkins Hosp 1939;64:1-21

13. Chalumeau M, Le Clainche L, Sayeg N, Sannier N, Michel JL, Marianowski R, et al. Spontaneous pneumomediastinum in children. Pediatr Pulmonol 2001;31:67-75. [CrossRef]

14. Gupta NM, Kaman L. Personal management of 57 consecutive patients with esophageal perforation. Am J Surg 2004;187:58-63. [CrossRef]

15. Karabacak K, Genc G, Gundogdu G, Bakir A. Recurrent spontaneous pneumomediastinum and pneumorrhachis accompanied by Raynaud's phenomenon. Turkish J Thorac Cardiovasc Surg 2013;21:1086-9. [CrossRef]

16. Laennec R. A treatise on diseases of the chest and on mediate auscultation. New York: Samuel Wood Sons; 1830. 
ORİJINAL ÇALIŞMA - ÖZET

\section{Pnömomediastinumların klinik deneyimlere dayalı olarak karşılaştırılması}

Dr. Ersin Sapmaz,, Dr. Hakan Işık, ${ }^{1}$ Dr. Deniz Doğan, ${ }^{2}$ Dr. Kuthan Kavaklı, ${ }^{1}$ Dr. Hasan Çaylak

${ }^{1}$ Gülhane Eğitim ve Araştırma Hastanesi, Göğüs Cerrahisi Anabilim Dalı, Ankara

${ }^{2}$ Gülhane Eğitim ve Araştırma Hastanesi, Göğüs Hastalıkları Anabilim Dalı, Ankara

AMAÇ: Pnömomediastinum (PM) mediastende hava varlığını tanımlayan terimdir. Ayrıca mediastinal anfizem olarakta tanımlanmıştır. PM, spontan PM (SPM) ve sekonder PM (ScPM) olarak adlandırılan iki alt gruba ayrilır.

GEREÇ VE YÖNTEM: Şubat 2010 ve Temmuz 2018 arasında tanı konulan PM'nin karşılaştırmalı geriye dönük bir çalışması sunuldu. Kırk hasta karşılaştıııldı. Hasta öyküsü, fiziksel özellikleri, semptomları, muayene bulguları, hastanede kalış süresi, tedavileri, klinik süreci, nüks ve komplikasyonları ile ilgili klinik veriler dikkatli bir şekilde araştıııldı. SPM, travmatik PM (TPM) ve iyatrojenik PM (IPM) olan hastalar karşılaştırıldı.

BULGULAR: SPM I 4 hastada (\%35) tespit edildi. ScPM grubunda; 16 hastada (\%40) TPM, 10 hastada (\%25) iyatrojenik PM tespit edildi. SPM grubunda en sık bildirilen semptomlar göğüs ağrısı, dispne, subkütanöz amfizem ve öksürük idi. Tanıyı doğrulamak ve olası bulguları değerlendirmek için tüm hastalara BT uygulandı. Tüm hastalara mediastiniti önlemek için profilaktik antibiyotik reçete edildi.

TARTIŞMA: Bu çalışmanın temel amacı, travma ve travma dışı hastalardaki PM'lerin klinik farklılıklarını ve yönetimini değerlendirmektir. Pnömomediastinumun klinik spektrumu, benign mediastinal anfizemden mediastinal yapıların perforasyonu nedeniyle ölümcül bir mediastinite kadar değişebilir. Birçok çalışmada sadece SPM pek çok açıdan değerlendirilmiştir, ancak travmatik ve travmatik olmayan PM'lerin değerlendirmesini ve yönetimini karşılaştıran daha az çalışma vardır. Sadece toraks bölgesine sınırlı travma geçiren ve görüntüleme çalışmalarında mediastinal organ hasarı olmadı̆̆ı gösterilen TPM'li hastalar, mediastinal organ yaralanmasına sahip olmayan SPM hastalar gibi takip ve tedavi edilebilir.

Anahtar sözcükler: Mediastinal amfizem; mediastinit; spontan pnömomediastinum; travmatik pnömomediastinum.

Ulus Travma Acil Cerrahi Derg 2019;25(5):497-502 doi: 10.14744/tjtes.2019.03161 